\title{
Equatorial
}

v.8 n.14 | jan/jun 2021

ISSN: $2446-5674$

\section{Editorial: \\ Decolonialidades, cosmovisões e territórios epistemológicos em tempos de negacionismos}

O compromisso de compreender o mundo e as relações que o conformam tem sido um dos pilares históricos da Antropologia. Esse compromisso tornou-se mais importante e mais difícil num contexto que combina ataques ao conhecimento científico, desinvestimento em educação, incentivo à desinformação e crise sanitária. Combinação que tem transformado e tornado cada vez mais difíceis as relações sociais e a própria produção científica que, duramente confrontada e atacada em um dos momentos mais críticos da humanidade, é precisamente o que tem chamado a fazer frente a outro grande inimigo: o negacionismo.

Neste contexto, no qual o Brasil tem se tornado uma das referências mundiais em negacionismo e má gestão política, social e sanitária, apresentamos o número 14 da Revista Equatorial, em mais uma edição produzida em tempos de pandemia. Este número reúne seis artigos, uma tradução e três ensaios visuais, que mostram, ao mesmo tempo, que o fazer científico antropológico e a produção acadêmica estão sendo profundamente afetados pela Covid-19, mas que continuam sendo fundamentais para compreendermos as relações e os processos sociais contemporâneos.

A gestão, ou a falta de gestão, da crise sanitária e social se transformou num genocídio assistido por todas/os nós que, trancafiadas/os em casa ou nos expondo ao cotidiano de transportes lotados e trabalhos precarizados, não sabemos como reagir. Contudo, é necessário dizer que não estamos conformadas/os, nem satisfeitas/os. Nosso sentimento é o desejo de justiça. A crise política que já se estende há cinco anos tem gerado um ambiente social que exige a organização em termos de lutas sociais. A crise na educação tem acentuado a luta das universidades públicas para manterem-se funcionando, ao mesmo tempo em que a Universidade tem sido a matriz geradora de movimentos 
contrários ao instante de obscurantismo que ainda estamos buscando compreender, analisar e explicar por meio do conhecimento científico.

É importante enfatizar que quando falamos em ciência, não falamos apenas do paradigma científico ocidental moderno. O conhecimento de povos indígenas, quilombolas e outras comunidades tradicionais, movimentos sociais organizados, organizações de pessoas que lutam pelos seus direitos etc, são igualmente importantes nesse processo de construção de uma (nova) noção de mundo e no desenvolvimento de uma disciplina que, como a antropologia, entende a necessidade de escutar e aprender outras formas de reflexão e conhecimento do mundo social. Muitas destas formas, especialmente as dos povos indígenas, foram desvalorizadas com o avanço da empreitada colonial, que devastou as formas de organização existentes no nosso continente, mas muitas dessas mantiveram-se apesar do contato com o pensamento colonial. De certa forma, a ciência tem enfrentando um negacionismo que as cosmovisões dos povos originários vêm enfrentando há vários séculos. No entanto, isso não é uma tentativa de polarização entre ciência e visões tradicionais, mas sim, o reconhecimento de uma grande tragédia que hoje se manifesta também contra as/os representantes dos saberes supostamente aceitos globalmente.

Novas formas de pensar sobre o fazer científico e sobre as relações globais implicadas, foram e são protagonizadas por intelectuais que enfrentaram o debate sobre como as relações coloniais desvalorizaram (e continuam desvalorizando) o conhecimento produzido na América Latina. Alguns destes debates saíram às luzes pelo esforço de pesquisadoras/es contemporâneas/os que buscam discutir sobre outras formas de pensar as relações raciais e de gênero na "América Latina" pós-colonial. Discutindo sobre como se construiu a noção contemporânea do continente, retomando-o como território político e epistemológico.

Por tanto, publicar traços das histórias, as agências, as formas de resistências de povos deste território, que é Abya Yala, por meio do fazer científico antropológico é uma forma de fortalecer o conhecimento aqui produzido e também de fortalecer a importância dos saberes e cosmovisões que fazem sentido na vida vivida dos povos andinos, dos grupos tradicionais, dos indígenas nos vários lugares do continente. Dos Andes peruano à Tierra del Fuego.

Dessa forma, entre os diversos temas que permeiam as páginas desta edição, a Universidade se apresenta como território de debate, um espaço público que abriga sujeitos diversos, e diversas reivindicações e desejos. Desde a luta pela sobrevivência 
mesma da universidade pública, até a batalha específica das mulheres mães, ou que maternam, durante a experiência estudantil na universidade. É um território não apenas de formação profissional, mas de embates, de desafios e de reivindicações. Encontramos esse assunto no ensaio visual $\mathrm{Na}$ luta: universidade pública em tempos de crise no qual há um retrato das lutas e da resistência pela sobrevivência da Universidade do Estado do Rio de Janeiro, e no artigo Corpos dissidentes no espaço universitário: temporalidade, perspectivas e necessidades de mulheres mães universitárias. Discutir o papel das universidades nunca foi tão importante nas últimas décadas quanto é agora.

A fotografia tem se tornado um importante instrumento no registro de fenômenos culturais, abrindo espaço também para a necessidade de um debate ético sobre seu uso na etnografia, esse debate apresentamos no artigo A quem pertence a imagem? Implicacõoes éticas sobre o uso da fotografia em trabalhos cientificos. Nesta edição, publicamos três ensaios visuais nos quais as fotografias ressaltam o papel da memória e sua relação com os lugares, evidenciando como as memórias atravessam os tempos e constroem futuros. Além do já citado ensaio $\mathrm{Na}$ luta, temos o ensaio Endereçados, com fogo, do fim do mundo manancial de memória e tinta nos muros de Ushuaia e Río Grande, Argentina, no qual perceber registrada nos muros como símbolo de luta política, a noção de memória nos muros da Tierra del Fuego evoca a presença indígena, desafiando sua tentativa de apagamento como resultado de séculos de colonialismo. A paisagem humana indígena, vibrante e viva, pode ser vista no ensaio Awaq warmi Tecendo os fios da cosmovisão andina, que retrata a relação entre os povos Quéchua e a produção artesanal das mulheres, que fazem do tecer de lã um patrimônio peruano, um aguayo colorido onde se carregam as wawas que têm perpetuado geracionalmente a cosmovisão andina.

Além disso, é possível encontrar neste número artigos que discutem práticas políticas e os festejos populares, como no artigo As políticas do patrimônio imaterial e seus impactos nos grupos da cultura popular na Festa de Santo Antônio em Barbalha/CE; aspectos de festas religiosas evangélicas na Amazônia paraense, em $A$ festa das primícias na comunidade amazônica de Vila Verde/Pará; e uma discussão referente à crise permanente da saúde indígena, no artigo Uma crise permanente: reflexões sobre a politica de saúde indígena a partir do caso do Alto Tapajós (PA). Das comunidades indígenas e tradicionais à antropologia urbana, os espaços mostrados são territórios que abrigam diferentes formas de existência, como é o caso de O pedaço: O Alto do Louvor sob a perspectiva de suas usuárias, que narra relações marcadas pela precariedade e pela reprodução de desigualdades. 
Por fim, a tradução realizada por Angela Facundo Navia do ensaio de Mara Viveros Vigoya, intitulada Discurso sobre o colonialismo de Aimé Césaire: uma chave de leitura feminista latinoamericana descolonial, é muito festejada por nós da revista, pois renova a importância de adotarmos uma perspectiva feminista latino-americana nas nossas leituras e análises antropológicos, desta vez impulsionada pela releitura que faz Viveros sobre a voz contracolonial de Aimé Césaire. O texto permite um diálogo entre as feministas latinoamericanas que ultrapassa as barreiras linguísticas impostas pelas características de nossa história colonial na região. Essa discussão tem um sentido contemporâneo de grande importância para as articulações políticas das mulheres, pois faz parte do processo de retomada das identidades coletivas que pensam o território Abya Yala como político e epistemológico.

Assim, convidamos as queridas e os queridos leitores a explorar os artigos deste número, desejosos em proporcionar uma reflexão sobre a importância da ciência e das cosmovisões para as interpretações do mundo em tempos sombrios. Aproveitamos para convidá-las/os a contribuir com a produção do conhecimento científico e do trabalho etnográfico enviando os resultados de suas pesquisas antropológicas para nossa revista.

Desejamos força nesses momentos difíceis e manifestamos nossa solidariedade com as/os familiares das vítimas da Covid-19.

Boa leitura!

Ester Corrêa 